\title{
DETERMINING THE RELATIONSHIP BETWEEN LEADERSHIP PRACTICES AND LEADERSHIP NEEDS IN SAUDI CONSTRUCTION COMPANIES
}

\author{
UDC: 005.322:316.46:[691:658.11(532) \\ Original Scientific Paper \\ Nasser Abdulkarim ALBAHALI ${ }^{1}$, Abdelnaser OMRAN ${ }^{2}$ \\ ${ }^{1}$ Blue Mars for Elevators: Imports and Maintenance, Jeddah City, Saudi Arabia \\ E-mail: naser_elamroni@yahoo.co.uk \\ ${ }^{2}$ School of Economic, Finance and Banking, College of Business, University Utara Malaysia, 06010, Sintok, Kedah \\ State, Malaysia
}

Paper received: 13.11.2017.; Paper accepted: 03.12.2017.

\begin{abstract}
Effective leadership is demonstrated by influencing and guiding the activities of the team toward achieving its goals. This study attempts to determine the relationship between leadership practices and leadership needs in construction companies in the Kingdom of Saudi Arabia. A postal questionnaire survey was conducted to achieve the main aim of this research. Questionnaires were mailed to 155 construction companies in Jeddah city between September and October 2012. Of these, only 138 questionnaires were returned and analyzed. Significant associations were found among all variables. It was found that the two dimensions' personal competence $(B=0.370, t=4.393$, $p<0.01)$ and professional competence $(B=0.312, t=3.05, p<0.01)$ as leadership needs were significant towards leadership practices. This study suggests that the company leader, director, executive and non-executive should give direct reports autonomously and encourage others to face challenges, solve problems, and develop their own accountability which could significantly increase the effectiveness of company leaders in the construction industry of the Kingdom of Saudi Arabia.
\end{abstract}

Keywords: Leadership, Practices, needs, Personal, Professional, Construction companies.

\section{INTRODUCTION}

Several international and local conferences and seminars have discussed the subject of management and leadership within the framework of identifying problems in developing countries. Recent reports by the World Bank indicate that the problem in developing countries, including the Arab states, is not resources, but management of resources. Japan was once one of the poorest countries in terms of natural resources, and yet it is now an economic giant. By contrast, Brazil is a country rich in natural resources but now suffers from debt, (Idris, 2009). The tenth annual conference of the Arab Organization for Development and Management, Alzniban (2009) shared that the current generation of leaders in private and public sectors need to be developed and refined to achieve high levels of administrative efficiency, which, in turn, will lead to achieving the desired goals of these companies. In 2009, leadership and change strategies in management and business were discussed in a forum in Riyadh, Saudi Arabia. In this forum, Atawaim (2009) stated that the Arab region, particularly, Saudi Arabia, is suffering from a crisis in leadership, and not management. The presence of leaders is required to change and apply the concepts of leadership and modern management. Leadership has been the theme of several university studies. These studies highlight one or more aspects of administrative leadership including Mira's letter (Mira, 2005) about the direction of Arab administrative leadership in light of globalization. Such concept of administrative leadership can be clarified through in-depth studies, and its application can be examined through a field survey. The lack of studies on a broad scale of Arab administrative leadership illustrates the global extent of possessing properties. In his letter, Dahas (2008) recommends mastery of leadership patterns to develop administrative leadership skills 
in government agencies in Jeddah. In discussing the problems of Saudi Arabian Airlines, AlQahtani (2011) explains that the current problems on care and government financial support are not reflected on the quality of performance of the company, which indicates that the problems are linked to the leadership of top departments in the airline. Al-Khalidi (2011) emphasizes an urgent need to formulate specific criteria, and clearly shows how quality of leadership is suited to the next phase. Therefore, plans and programs should be designed to develop the next generation of leaders who can effectively handle tasks according to the stage of growth of the institution. Improving leadership quality in Saudi Arabia requires identifying key factors that affect leadership styles and developing more effective managers or leaders. However, organizations and companies in Saudi Arabia require managers who have advanced understanding of leadership and use it to their advantage. Leadership is one of the most important subjects in management studies, (Toor \& Ofori, 2006; Toor \& Ofori, 2008). The lack of focus on leadership not only happens in practice. Academic research has also not dwelled much on the effectiveness of leadership in the construction industry, (Odusami et al., 2003; Chan \& Chan, 2005). Therefore, the present study seeks to describe leadership effectiveness and needs in companies within the construction industry of Saudi Arabia. Particularly, the present study aims to guide practitioners in developing effective and high-quality managers in these construction companies.

\section{LEADERSHIP NEEDS}

This part presents the types of leadership needs which are classified into two types namely: (1) personal and (2) professional needs.

\section{Personal needs}

An effective leader who has an appropriate leadership style for the situation and problem can enhance the performance of his or her followers. Effective leadership is demonstrated by influencing and guiding the activities of the team toward achieving its goals, (Judge et al., 2004). According to Jex (2002), goals direct our attention, focus our efforts, and help maintain task persistence, which helps individuals avoid becoming sidetracked. By guiding the group, a leader enhances group processes and facilitates the development of collective efficacy, influencing group outcomes, (Paul \& Ebadi, 1989; Chen \& Bliese, 2002; Foti \& Miner, 2003). According to Chen and Bliese (2002) the work experience, role clarity, and work-related stress of group members affect their beliefs of self-efficacy and performance outcomes. Effective leaders are clearly understood and can act quicker to achieve organizational goals, (Judge \& Piccolo, 2004). Moral aspects of leadership quality are not harmonized with technical aspects: either moral bewilderment or loss of ability can and does produce the collapse of character, (Barnard, 1948). Because "organizations endure in proportion to the breadth of morality by which they are governed" the authenticity of leadership can be measured by the moral capacity, courage, and resilience of the leader in creating commonly held codes within the organization, (Barnard, 1948). These challenges, together with rapid changes in business culture, have led to a widespread adoption of flattened organizational structures and empowerment strategies. To improve the operational flexibility of organizations, several new structures have emerged, such as networks, collaborations, federalist structures, the shamrock structure, and virtual organizations. Pries et al. (2004) noted that the mainstream paradigm of construction industry leaders is conventional in nature and remains technology and project oriented. They argue that industry leaders must take appropriate initiatives to change the old paradigms and make the construction industry more flexible in order to adapt to the modern business environment. Therefore, construction leaders need to develop the necessary capabilities to deal with future challenges. Fraser (2000) found that those who scored high on the effectiveness scale favor teamstyle leadership, those following a production style of leadership score the lowest, and those using a compromise leadership style had middle-range effectiveness scores. Contrary to earlier studies, in another study of project managers in Thailand, Ogunlana et al. (2002) found that the relationshiporiented leadership style is considered more important than the task-oriented style for project managers.

\section{Professional needs}

With the increased emphasis on project management systems, construction firms now give preference to professionals with better management and leadership skills over those with technical skills, (Dulaimi, 2005). The technical aspect reflects individual superiority in 
administrative and technological skills, which is "essential to positive action; commanding admiration, emulation", (Barnard, 1948). The moral aspect "gives dependability and determination to human conduct, and foresight and ideality to purpose", (Barnard, 1948). However, educational institutions and construction firms continue to produce managers who lack leadership skills. This is due to traditional academic curricula that do not cover the development of individuals as leaders, the conventional transactional mentality, and the task orientation of industry professionals. Previous works on the subject mention several reasons for this situation; the examples are technically focused curricula in engineering education, limitations on the standards of performance, requirements in standards and codes, and budget and time constraints, (Dulaimi, 2005). To address what may be called the "leadership crisis", Toor (2006) and George et al. (2007) argued that there is a need for leadership development among project heads in the construction industry. Chan and Chan (2005) found that all transformational factors (i.e., charisma, inspirational motivation, intellectual stimulation, and individualized consideration), as well as the contingent reward of transactional factors (i.e., contingent reward, management by exception, activeness and passiveness) are highly correlated with the rated outcomes of leader effectiveness, extra effort by employees, and satisfaction of employees with their leaders. Their study also reveals that the well-perceived leadership styles of building professionals are inspirational motivation, idealized attributes, intellectual stimulation, idealized behavior, contingent reward, and individualized consideration. Effective leaders understand the characteristics of their organizational culture and develop strategies, such as problem solving and communication styles, to influence the performance of their followers in order to inspire them to strive toward the achievement of department objectives and goals, (Katz \& Miller, 1996; O'Regan \& Ghobadian, 2004; Omran \& Akram, 2017). In addition to leading in their own organizations, leaders may also be required to work with other organizations.

\section{Leadership studies}

Leadership is one of the most important subjects in management studies; however, many authors have not been able to articulate the idea of leadership, despite the large volume of research and literature on the area, (Giritli \& Oraz, 2004; Omran et al., 2009; Omran et al., 2011). Particularly, in the construction industry, few studies have been conducted on leadership, (Odusami et al., 2003). Dulaimi and Langford (1999) argue that most studies on leadership in the construction industry concentrate on investigating the personal characteristics of project managers. Few have focused on leadership development and methods of staff motivation in the construction industry. However, due to the changing environment of said industry and the increasing realization of the people-side of project management, researchers have shown more interest on it during the last few years, (Toor \& Ofori, 2007; Limsila \& Ogunlana, 2008; Omran et al., 2009). In their research on Thailand construction companies, Limisla and Ogunlana (2008) show the correlation between leadership behavior and work performance. According to their study, work quality has a positive significant relationship with inspirational motivation and idealized influence (attributed) in the transformational leadership style. Clark et al. (2009) reported that a manager's leadership style has a tremendous influence on employees' behavior, including their adoption of the firm's strategic and marketing initiatives, particularly those relating to customer service. In their study on the relationship among project leadership, team composition, and construction project performance in Nigeria, Odusani et al. (2003) concluded that there is a significant relationship among the professional qualifications of the project leader, his or her leadership style, team composition, and overall project performance. In contrast, with an increased emphasis on project management systems, construction firms are now seeking professionals with better management and leadership skills, rather than technical skills, (Dulaimi, 2005). Omran et al. (2011) conducted a study to identify the key factors for effectiveness leadership in Libya and how they contribute to the success of construction companies. As a result, the study revealed that all the functional competence factors included in the survey show a positive and significant relationship with company establishment and strategy management system (SMS). Furthermore, the results identified some functional competence factors showing significant contribution to an effective leadership in the Libyan construction industry. According to research, many construction projects face various problems, which can often be traced to the project managers or leaders. Some of them may have insufficient competencies, or their traits may not fit 
the nature of work. Furthermore, these leasers may use inappropriate leadership styles in dealing with their subordinates in construction projects. In contrast, some studies have been conducted on the roles and effects of project managers and site managers on the quality and success of construction projects. For instance, Murphy and Ledwith (2007) and Arain (2007) indicated that the project manager is one of the most important success factors of projects. Moreover, the study of Herbert et al. (1970) showed that site managers have an effect on the overall quality and cost of the project, and that quality of an individual site manager may affect the project cost by as much as 10\%. Caughron and Mumford (2012) conducted a study on how a leader's superior impacts middlemanagement performance. It was found that a leader's superior can influence their leadership behavior in a complex manner. Participant sense making was higher when their superior emphasized low levels of individual (or personal) consequences. Participative leadership was higher when the supervisor framed organizational level consequences as being high. Findings for participant confidence were complex, but they generally suggest that one's superiors can promote or hinder confidence in a variety of situations. Gardner et al. (2011) conducted a study on authentic leadership by reviewing the past studies. They reviewed this literature with the goal of clarifying the state of knowledge in the field. Gardner et al. (2011) provided a roadmap for further advancing authentic leadership theory, research, and practice, and thereby enable organizations to more fully realize the elevated levels of sustained and veritable performance that a leadership process grounded in authenticity has the potential to provide. Zhu et al. (2013) examined the mediating effects of cognitive and affective trust on the relationship between follower perceptions of transformational leadership behavior and their work outcomes. As findings, Zhu et al. (2013) highlighted the importance of effective trust as a mechanism which translates transformational leadership into positive work outcomes for the organization. Li et al. (2012) examined the genetic and environmental associations between transformational leadership and leadership role occupancy. As results, Li et al. (2012) showed that $78 \%$ of the covariance between the two leadership variables was attributable to overlapping genetic factors, while $22 \%$ of the covariance to overlapping environmental factors. In particular, $13 \%(2 \%)$ of the variance in leadership role occupancy was accounted for by the same genetic (environmental) factors related to transformational leadership. Unique sets of genetic and environmental variables, which are not associated with transformational leadership, explained $16 \%$ and $69 \%$ of the variance in leadership role occupancy, respectively.

\section{THE STUDY AREA}

Jeddah is a city located on the coast of the Red Sea and is the major urban center of western Saudi Arabia. It is the largest city in Mecca Province, the largest sea port on the Red Sea, and the second largest city in Saudi Arabia after the capital city, Riyadh (See Figure 1). With a population currently at 3.2 million, Jeddah is an important commercial hub in Saudi Arabia. Jeddah is the principal gateway to Mecca, Islam's holiest city, which able-bodied Muslims are required to visit at least once in their lifetime. It is also a gateway to Medina, the second holiest place in Islam. Economically, Jeddah is focusing on further developing capital investment in scientific and engineering leadership within Saudi Arabia and the Middle East. Jeddah was independently ranked 4th in the Africa / Mid-East region in terms of innovation in 2009 in the Innovation Cities Index. Jeddah is one of Saudi Arabia's primary resort cities and was named a Gamma world city by the Globalization and World Cities Study Group and Network. Historically, Jeddah has been well known for its legendary money changers.

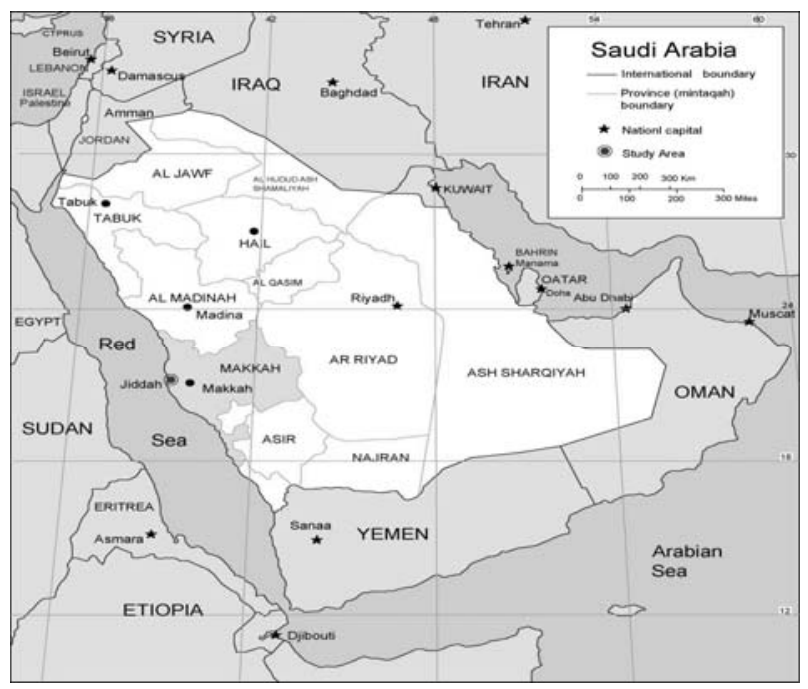

Figure 1: Map of Saudi Arabia with the selected city for the study in Red Colour

\section{RESEARCH METHOD}

This study was attempted to determine the relationship between leadership practices and 
leadership needs in the construction companies in the Kingdom of Saudi Arabia. Data was collected using the questionnaire survey method. Questionnaires, which total to 155 , accompanied by cover letters, were sent out to leaders, directors, executives and non-executives in the construction companies in Jeddah city. In the end, 139 completed questionnaires were returned. Of these, 138 became the respondents, and their responses were analyzed. The data collected was processed by using Statistical Package for Social Science (SPSS) program for Windows (Version 19.0). In order to test the relationship between the independent variable and the dependent variable in the construction companies in Jeddah city), the following hypothesis was proposed:

$H_{1}$ : Leadership in the construction companies in Jeddah city has a positive relationship with leadership needs.

\section{RESULTS ANALYSIS}

\section{Background of the Respondents}

Out of 139 respondents, 138 of them were usable and analyzed. Table 1 described the distribution of the respondents according to their demographic background. 46.4 percent of the respondents were non-executive employees, while 21.0 percent were executive, 21.7 percent managers and 10.9 percent were a director. They were from various company status such as partnership (23.2\%), limited partnership (14.5\%), particular partnership (7.2\%), joint stock Company $(6.5 \%)$, private limited company by shares $(8.7 \%)$, limited liability Company (21.7\%), and company with changeable capital $(14.5 \%)$ and cooperative company (3.6\%). Almost half of the respondents $(47.8 \%)$ had been involved in the construction industry between 1 to 5 years. Most of the companies (48.6\%) were established for more than 20 years. Majority of the companies were also applied ISO 9000 management system (42.8\%), compared to TQM (11.6\%), TPM (15.2\%) and conventional system (30.4\%). 75.4 percent of the respondents were BSc degree holders, 21 percent were MSc degree holders, and only 3.6 percent were doctorate holders.

\section{Level of Leadership Satisfaction}

Respondents were asked to rate their level of satisfaction with the current practice of leadership in the construction companies in Jeddah city.
Satisfaction level was measured on a 5-point Likert scale $(1=$ very dissatisfied; $2=$ dissatisfied; $3=$ neutral; $4=$ satisfied and $5=$ very satisfied). The results had shown that sixty-two respondents $(44.6 \%)$ mentioned that they were neither dissatisfied nor satisfied followed by forty-one respondents $(29.5 \%)$ who mentioned that they were unsatisfied with the current practice while only eleven respondents $(7.9 \%)$ who did indicate that they very unssatisfied with the leadership practices in the construction companies in Jeddah. Surprisingly, it was found that only five respondents $(3.6 \%)$ mentioned that they were very satisfied and twenty of the participants (14.4\%) indicated that they were satisfied.

Table 1: Background of the Respondents

\begin{tabular}{|c|c|c|}
\hline & Frequency & Percentage \\
\hline \multicolumn{3}{|l|}{ Designation } \\
\hline Director & 15 & $10.9 \%$ \\
\hline Manager & 30 & $21.7 \%$ \\
\hline Executive & 29 & $21.0 \%$ \\
\hline Non-executive & 64 & $46.4 \%$ \\
\hline \multicolumn{3}{|l|}{ Company Status } \\
\hline Partnership & 32 & 23.2 \\
\hline Limited Partnership & 20 & 14.5 \\
\hline Particular partnership & 10 & 7.2 \\
\hline Joint stock company & 9 & 6.5 \\
\hline $\begin{array}{l}\text { Private company limited by } \\
\text { shares }\end{array}$ & 12 & 8.7 \\
\hline Limited Liability Company & 30 & 21.7 \\
\hline $\begin{array}{l}\text { Company with changeable } \\
\text { capital }\end{array}$ & 20 & 14.5 \\
\hline Cooperative company & 5 & 3.6 \\
\hline \multicolumn{3}{|l|}{ Working Experience } \\
\hline $1-5$ years & 66 & 47.8 \\
\hline $6-10$ years & 30 & 21.7 \\
\hline $11-15$ years & 21 & 15.2 \\
\hline More than 20 years & 21 & 15.2 \\
\hline \multicolumn{3}{|l|}{ Company Age } \\
\hline $1-5$ years & 22 & 15.9 \\
\hline $6-10$ years & 17 & 12.3 \\
\hline $11-15$ years & 32 & 23.2 \\
\hline More than 20 years & 67 & 48.6 \\
\hline \multicolumn{3}{|l|}{ Strategy Management System } \\
\hline ISO 9000 & 59 & 42.8 \\
\hline TQM & 16 & 11.6 \\
\hline TPM & 21 & 15.2 \\
\hline Conventional system & 42 & 30.4 \\
\hline \multicolumn{3}{|l|}{ Education Background } \\
\hline BSc degree & 104 & 75.4 \\
\hline MSc degree & 29 & 21 \\
\hline $\mathrm{PhD}$ & 5 & 3.6 \\
\hline
\end{tabular}

\section{Reliability of the Variables}

To ensure the reliability of the scales, internal consistency confirmation of the scales was 
performed by checking the Cronbach's alpha coefficient. The cut-off point for measuring the reliability for this study is coefficient alpha of above 0.7 as recommended by Sekaran and Bougie (2010), Zickmund (2009) and Cresswell (2008). Table 2 exhibits the Cronbach coefficient alpha of the variables. All the variables in this study have values more than 0.7 .

Table 2: Reliability Coefficients of the Variables

\begin{tabular}{|c|c|c|}
\hline Construct & N of Item & $\begin{array}{c}\text { Cronbach } \\
\text { Alpha }\end{array}$ \\
\hline \multicolumn{2}{|c|}{ Project Leadership Needs } \\
\hline Personal Competence & 10 & 0.838 \\
\hline Professional Competence & 20 & 0.905 \\
\hline
\end{tabular}

\section{Descriptive Analysis}

Table 3 summarized the descriptive analysis to find the leadership needs in construction companies in Jeddah city. Results showed that company leadership needs (mean $=4.14$, $\mathrm{sd}=0.45$ ) scored the highest. In company leadership needs, professional competences (mean $=4.16, \mathrm{sd}=0.49$ ) were perceived as more important compared to personal competences (mean $=4.11, \mathrm{sd}=0.58$ ).

Table 3: Descriptive Analysis of the Variables

\begin{tabular}{|l|c|c|c|}
\hline $\begin{array}{l}\text { Project Leadership } \\
\text { Needs }\end{array}$ & 4.1380 & 0.44828 & High \\
\hline Personal Competence & 4.1145 & 0.57839 & High \\
\hline $\begin{array}{l}\text { Professional } \\
\text { Competence }\end{array}$ & 4.1616 & 0.48576 & High \\
\hline
\end{tabular}

The relationship between Leadership Practices and Leadership Needs

Regression analysis was carried out to study the effect of leadership concept on leadership practices in Saudi construction companies. It is shown in Table 4 that company leadership needs influenced leadership practices in Saudi construction companies for 26.5 percent $\left(\mathrm{R}^{2}=0.265, \mathrm{~F}=24.329\right.$, $\mathrm{p}<0.01)$. Both dimensions in this concept were also having significant predictions towards leadership practices where personal needs were $(B=0.370$, $\mathrm{t}=4.393, \mathrm{p}<0.01)$ and professional needs were $(\mathrm{B}=0.312, \mathrm{t}=3.05, \mathrm{p}<0.01)$.

\section{CONCLUSION}

The first research objective was to determine the level of satisfaction with the current practice of leadership in the construction companies in Jeddah city. However, as a conclusion, it can be stated that the level of satisfaction was rated as "neither unsatisfied nor satisfied" followed by unsatisfied". Therefore, there is a need to improve the current practices of leadership in the construction companies in Jeddah city. Based on the findings, it can be concluded that company leadership needs influenced leadership practices in Saudi construction companies and both dimensions of personal and professional competences also had significant predictions towards leadership practices. This study has come with some recommendations (i) the company leader, director, executive and non-executive should give direct reports autonomously and encourage others to face challenges, solve problems, and develop their own accountability; (ii) the company leader, director, executive and non-executive must encourage others to take on ever increasing demanding tasks, roles, and accountabilities. He or she should develop others' competences and invest time and effort in coaching them. However, one of the limitations of the study relates to the sector. Since this study was applied in construction companies, some future research can examine different types of sectors which we consider interesting.

Table 4: Effect of Project Leadership Needs on Leadership Practices

\begin{tabular}{|c|c|c|c|}
\hline & $\mathrm{B}$ & $\mathrm{t}$ & Sig. \\
\hline \multicolumn{3}{|c|}{ Company Leadership Needs } \\
\hline $\begin{array}{c}\text { Personal } \\
\text { Competence }\end{array}$ & 0.370 & 4.393 & 0.000 \\
\hline $\begin{array}{c}\text { Professional } \\
\text { Competence }\end{array}$ & 0.312 & 3.105 & 0.002 \\
\hline $\mathrm{R}^{2}$ & 0.265 & & \\
\hline $\mathrm{F}$ & 24.329 & & \\
\hline Sig. & 0.000 & & \\
\hline
\end{tabular}

\section{ACKNOWLEDGEMENT}

The authors are grateful to the respondents who had participated in this study.

\section{REFERENCES}

Al-Khalidi, P. (2011). Leadership between the moods and standards. Retrieved October 18, 2016, from Magazine "Today" http://www.alyaum.com

Al-Qahtani, P. (2011). Reform of Saudi Arabian Airlines. Retrieved October 12, 2016, from Magazine "Today" http://www.alyaum.com

Alzniban, M. (2009). Arab management and the challenges of quality and global levels. Paper presented at the Arab Conference of the tenth annual, Cairo, Egypt. 
N. A. Albahali Determining the relationship between leadership practices and

Arain, P. M. (2007). Critical Success Factors of Project Management Practices in Pakistan's Construction Industry. Construction Information Quarterly, 9(4), 179-185.

Atawaim, N. (2009). Leadership and Change Strategies. Business and Management Forum, Riyadh, Saudi Arabia.

Barnard. C. (1948). Organization and Management. Cambridge, MA: Harvard University Press.

Caughron, J.J., \& Mumford, M.D. (2012). Embedded leadership: How do a leader's superiors impact middle-management performance? The Leadership Quarterly, 23, 342-353.

Chan, A.T., \& Chan, E.H. (2005). Impact of perceived leadership styles on work outcomes: ease of building professionals. Construction Engineering and Management, 131(4), 413-22.

Chen, G., \& Bliese, P.D. (2002). The role of different levels of leadership in predicting self- and collective efficacy: Evidence for discontinuity. Journal of Applied Psychology, 87(3), 549-556.

Clark, R., Hartline, M., \& Jones, K. (2009). The effects of leadership style on hotel employees' commitment to service quality. Cornell Hospitality Quarterly, 50(2), 209-216.

Cresswell, J.W. (2008). Research Design: Qualitative and Quantitative Approaches. Thousand Oaks, C.A: Sage Publication, Inc.

Dahas, S.S. (2008). Patterns of administrative leadership in government agencies in Jeddah. King Abdulaziz University, Saudi Arabia.

Dulaimi, M., \& Langford, D.A. (1999). Job behaviour of construction project managers: determinants and assessment. Journal of Construction Engineering and Management, 125 (4), 256-64.

Dulaimi, M.F. (2005). The influence of academic education and formal training on the project manager's behaviour. Journal of Construction Research, 6 (1), 1 79-93.

Foti, R.J., \& Miner, J.B. (2003). Individual differences and organizational forms in the leadership process. The leadership Quarterly, 14 (1), 83-112.

Frascr, C. (2000). The influence of personal characteristics on effectiveness of construction site managers. Construction Management and Economics, 18(1), 29-36.

Gardner, W.L., Cogliser, C.C., Davis, K.M., \& Dickens, M.P. (2011). Authentic leadership: A review of the literature and research agenda. The Leadership Quarterly, 22, 1120-1145.

George, B., Sims, P., McLean, A.N., \& Mayer, D. (2007). Discovering your authentic leadership. Harvard Business Review, 85 (2), 129-38.

Giritli, I.I., \& Oraz, G.T. (2004). Leadership styles: some evidence from the Turkish construction industry. Construction Management and Economics, 22, 253262.

Herbert, A., Martvall, K., \& Wirdenius, H. (1970). Site management and production disturbances. Build 7"ech Manage, 7, 19-20.
Idris, M.A. (2009). Director of the Pillars of Excellence in the Arab Environment, Zagazig: Modern University Library.

Jex, S.M. (2002). Organizational psychology: A scientist-practitioner approach. New York: Wiley.

Judge, T.A., \& Piccolo, R.F. (2004). Transformational and transactional leadership: A meta-analytic test of their relative validity. Journal of Applied Psychology, 89 (5), 755-765.

Judge, T.A., Colbert, A.E., \& Hies, R. (2004). Intelligence and leadership: A quantitative review and test of theoretical propositions. Journal of Applied Psychology, 89 (3). 542-552.

Katz, J.H., \& Miller, F.A. (1996). Coaching leaders through culture change. Consulting Psychology Journal: Practice and Research, 48 (2), 104-114.

Li, W.D., Arvey, R.D., Zhang, Z., \& Song, Z. (2012). Do leadership role occupancy and transformational leadership share the same genetic and environmental influences? The Leadership Quarterly, 23, 233-243.

Limsila, K., \& Ogunlana, S. (2008). Performance and leadership outcome correlates of leadership styles and subordinate commitment. Engineering, Construction and Architectural Management, 15(2), 164-184.

Mira, S. (2005). Directed administrative leadership in the Arab context of globalization. Alexandria: Dar thought the university.

Murphy, A., \& Lcdwith, A. (2007). Project management tools and techniques in high-technology SMEs. Management Research News Journal, 30(2), 153166.

Odusami, K.T., Iyagba, R.R., \& Omirin, M.M. (2003). This relationship between project leadership, team composition and construction project performance in Nigeria. International Journal of Project Management, 21 (7), 519-27.

Ogunlana, S.O., Siddiqui, Yisa, S., \& Olomolaiye, P. (2002). Factors and procedures used in matching project managers to construction projects in Bangkok. International Journal of Project Management, 20 (5), 385-400.

Omran, A., Alsadey, S.M., Pakir, A.K., \& Ramli, M. (2011). Functional Competencies' as an Effective Factor for Project Leaders in the Libyan Construction Industry. The Manager Journal, 15,123-131.

Omran, A., Mahmood, A., \& Hussin, A. (2009). Leadership: How to be an effective manager. Journal of Academic Research in Economic, 1(5), 13-21.

Omran, A., \& Akram, S.H.S. (2017). Identifying the competence components of the construction project managers in the Palestinian construction industry. Engineering Project Organization Journal, 1(5), 135-160.

O'Regan, N., \& Ghobadian, A. (2004). Leadership and strategy: Making it happen. Journal of General Management, 29 (3), 76-92. 
Paul, R.J., \& Ebadi, Y.M. (1989). Leadership decision making in a service organization: A field test of the Vroom-Yetton model. Journal of Occupational Psychology, 52, 201-211.

Pries, F., Doree, A., Van Der Veen, B., \& Vrijhoef, R. (2004). The Role of leaders' paradigm in construction industry change. Construction Management and Economics, 22, 7-10.

Sekaran, U., \& Bougie, R. (2010). Research Methods for Business: A Skill Building Approach. UK: John Wiley \& Sons.

Toor, S. R., \& Ofori, G. (2006, October 18-20). An antecedental model for leadership development. Paper presented at the Joint CIB W65/W55/W86 Symposium, Construction in 21st Century: Local and Global Challenges., Rome, Italy.

Toor, S.R. (2006). Leadership flashback: an antecedental approach to authentic leadership development. In: Proceedings of the second biennial gallup leadership institute summit, October, Washington (DC), USA.

Toor, S.R., \& Ofori, G. (2007). Leadership for future construction industry: Agenda for authentic leadership. International Journal of Project Management, 26(6), 620-630.

Toor, S.R., \& Ofori, G. (2008). Tipping points that inspire leadership; an exploratory study of emergent project leaders. Engineering, Construction and Architectural Management, 75(3), 212-29.

Zhu, W., Newman, A., Miao, Q., \& Hooke, A. (2013). Revisiting the mediating role of trust in transformational leadership effects: Do different types of trust make a difference? The Leadership Quarterly, 24(1), 94-105.

Zickmund, W.G. (2009). Exploring Marketing Research: Thomson/South-Western.

\title{
ODREĐIVANJE ODNOSA MEĐU LIDERSKIM PRAKSAMA I LIDERSKIM POTREBAMA U SAUDIJSKIM GRAĐEVINSKIM KOMPANIJAMA
}

\begin{abstract}
Efektivno liderstvo se predstvlja putem uticaja i vođenja timskih aktivnosti sa ciljem postizanja postavljenih ciljeva. Ovo istraživanje nastoji da uspostavi odnos između rukovodnih praksi i potreba liderstva u građevinskim kompanijama u Kraljevini Saudijskoj Arabiji. Ispitivanje je izvršeno putem poštanog upitnika da bi se postigao glavni cilja. Upitnici su upućeni u 155 gradevinske kompanije u gradu Jeddah, u periodu od septembra do oktobra 2012. Od toga je vraćeno i analizirano 138 upitnika. Pronađene su značajne asocijacije među svim varijablama. Utvrđeno je da su dve dimenzije, lične kompetencije $(B=0.370, t=4.393, p<0.01)$ i stručna osposobljenost $(B=0312, t=3.05, p<0.01)$ kao potrebe lidestva bile značajne u odnosu na rukovodnu praksu. Ova studija sugeriše da bi lider kompanije, direktor, izvršni i ne-izvršni trebao samostalno da daje direktne izveštaje i podstiče druge da se suoče sa izazovima, rešavaju probleme i razviju vlastitu odgovornost. Ovo može značajno da poveća efikasnost lidera preduzeća, posebno u građevinskoj industriji Kraljevine Saudijske Arabije.
\end{abstract}

Ključne reči: Liderstvo, Prakse, Potrebe, Lično, Profesionalno, Građevinske kompanije. 